\title{
The Relationship Between International Capital Flows and Industrial Upgrading in China
}

\author{
Lihui Wang ${ }^{*}$ \\ School of Statistics and Mathematics, Zhejiang Gongshang University, Hangzhou 310000,China \\ wh310033@163.com
}

\begin{abstract}
Keywords: International capital flow. Industrial upgrading. Education development. Energy consumption.

Abstract. In order to study the relationship between international capital flows and industrial upgrading in China, the Generalized Method of Moments (GMM) was applyed in this paper on the basis of the existing literature research. The conclusion is that the international capital flows promote the industrial upgrading in China. The innovation of this paper is that it studied industrial upgrading from such aspects as internatioal capital, education development and energy consumption.
\end{abstract}

\section{Introduction}

Many scholars have studied the total factor productivity from different perspectives (Marcel Forster et al., 2014; Jan in't Veld et al., 2014; Cédric Tille and Eric van Wincoop, 2014 ; Keisuke Okada, 2013; Thorsten Janus and Daniel Riera-Crichton, 2013). Rebecca M. Neumann (2006) examined the effects of capital controls on the volume and composition of international capital flows in the presence of asymmetric information. Martin D.D. Evans and Viktoria V. Hnatkovska (2014) presented a model to examine how greater integration in world financial markets affected the behavior of international capital flows and financial returns. Dennis Reinhardt and Luca Antonio Ricci (2013) revisit the Lucas paradox to account for the role of capital account openness and gain the conclusion that when accounting for such openness, the prediction of the neoclassical theory was empirically confirmed: among financially open economies, less developed countries tend to experience net capital inflows and more developed countries tend to experience net capital outflows. Alberto Martin and Filippo Taddei (2013) fill this gap by developing a standard growth model with adverse selection to study the topic of International capital flows and credit market imperfections. Cédric Tille and Eric van Wincoop (2010) developed the implications of portfolio choice for both gross and net international capital flows in the context of a simple two-country dynamic stochastic general equilibrium (DSGE) model. Endogenous time-variation in expected returns and risk, which are the key determinants of portfolio choice, affect capital flows in often subtle ways. The model is onsistent with a broad range of empirical evidence.

Based on the existing literature research, this paper studied the relationship between the international capital flows and the industry structure in China from 1982 to 2013.

\section{Model, Index and Data}

This paper mainly studied the relationship between international capital flows and industrial upgrading in China. In addition, this paper introduced education development and energy consumption as control variables.

Industrial upgrading. This paper uses the ratio of the tertiary GDP and the total amount GDP to represent industrial upgrading, expressed by $I S$. Taking the logarithm of $I S$ we get LNIS.

International capital flows. This paper uses the ratio of total sum of capital and financial projects in the international balance of payments which deflated by GDP deflator to represent international capital flows, expressed by $C F$. Taking the logarithm of $C F$ we get $L N C F$.

Education Development. Education level is related to the level of scientific and technological development of a country. Therefore, it has an impact on economic development, also affects the industrial structure. Therefore, this paper introduces the level of education development as the impact 
factor of industrial structure. Since higher education students are usually the human capital reserve forces of the scientific and technological development, "The average number of students in Colleges and Universities per one hundred thousand people" is applied by the index of "educationg development", expressed by EDU. Taking the logarithm of $E D U$ we get $L N E D U$.

Energy Consumption. Energy consumption is the material basis for the development of various industries, and industrial structure adjustment is the need of saving energy consumption and changing the growth mode. So the level of energy consumption has a certain impact on industrial structure adjustment. "total energy consumption (ten thousand tons of standard coal)" is applied by the index of "energy consumption", expressed by $E U$. Taking the logarithm of $E U$ we get $L N E U$.

Data in this paper are derived from the CSMAR database, the website of the Nationgal Bureau of Statistics of the People's Republic of China and the Baidu Encyclopedia.

\section{Empirical Analysis}

Variable graph analysis. Before the construction of the model, the variable graphs are analyzed. The figure of the variable $C F$ is shown in figure 1.The figure of the variable $E D U$ is shown in figure 2.The figure of the variable $E U$ is shown in figure 3. The figure of the variable $I S$ is shown in figure 4.

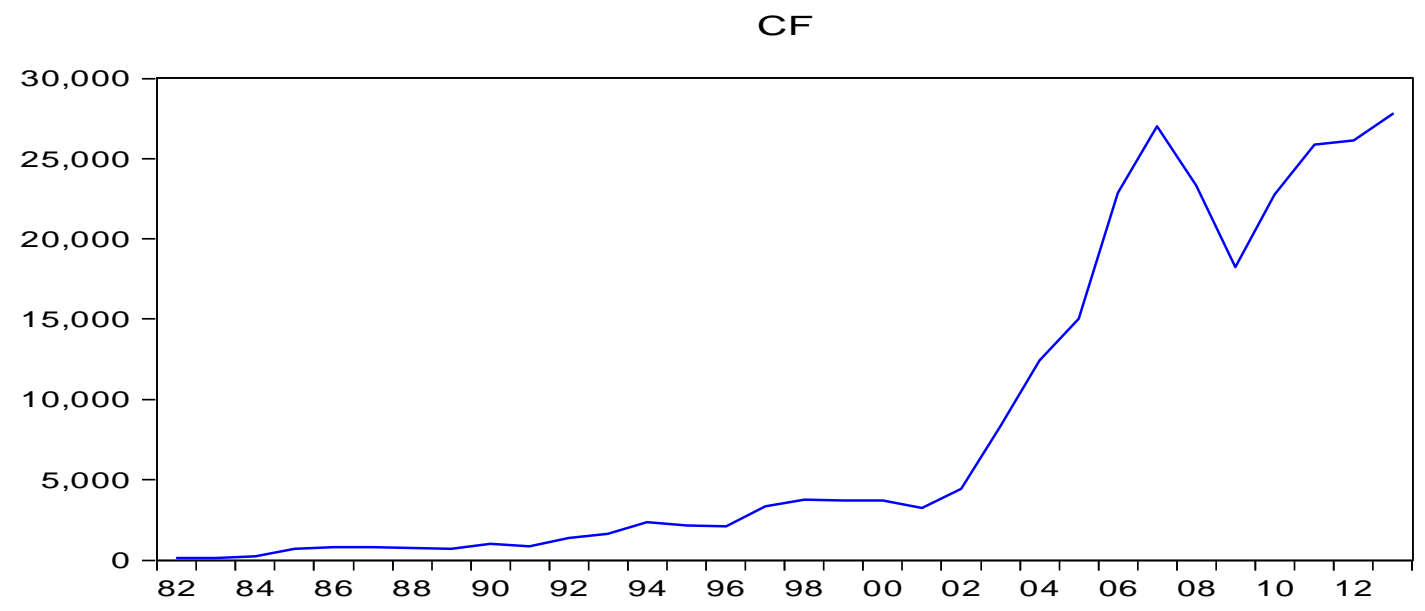

Figure1 International Capital Flow $C F$

According to figure (1), with the increase of China's international economic exchanges and cooperationthe, the international capital flows have a substantial increase after 2002.

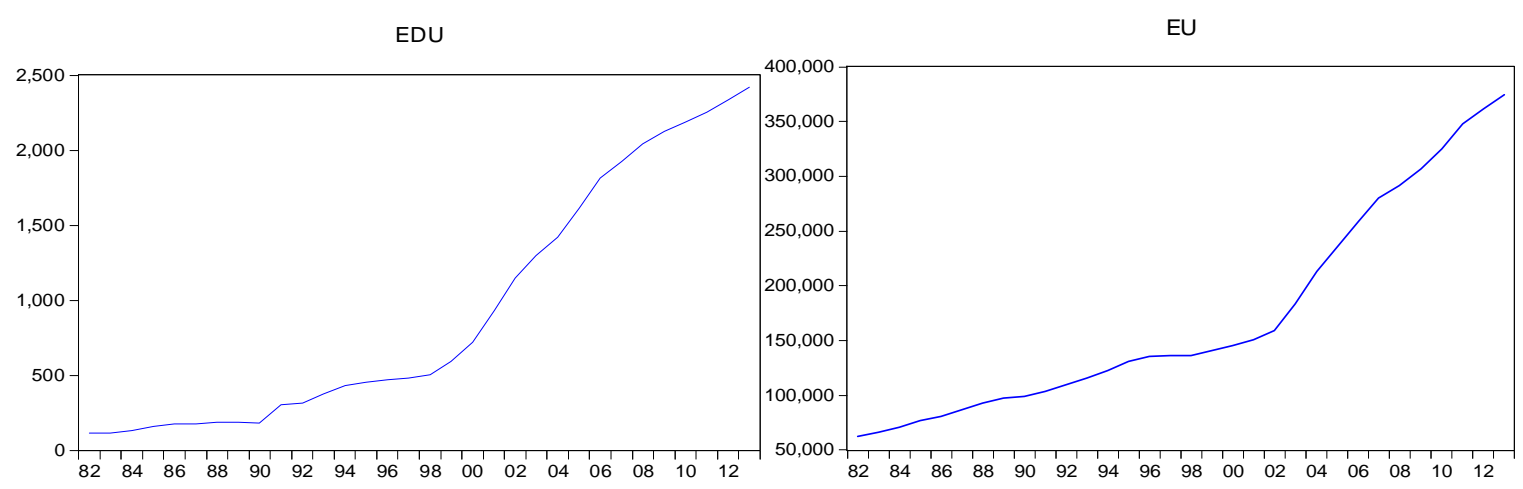

Figure2 Education Development EDU

Figure3 Energy Consumption $E U$

According to figure (2), the education development have a substantial increase after 1998. According to figure (3), the energy consumption have a substantial increase after 2002. 
IS

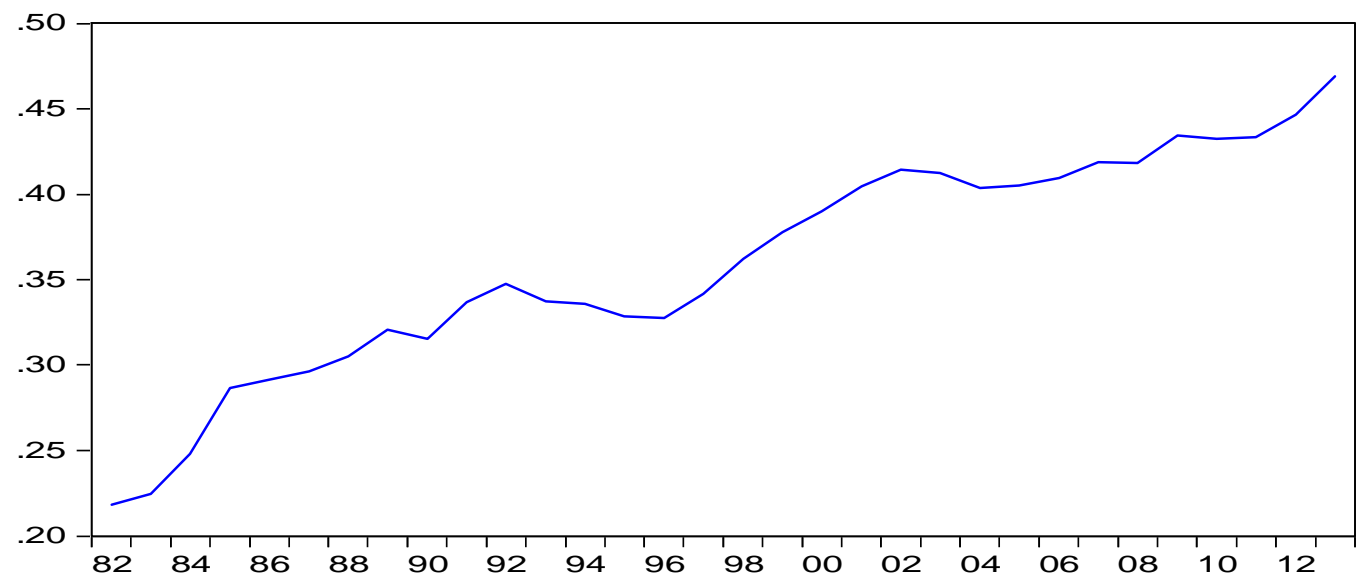

Figure4 Industrial upgrading $I S$

According to figure (4), China's industry is in a steady process of upgrading from 1982.

Stationary Test. Before the construction of the model, it is need to test the stationarity of the sequence. If the stationarity of the sequence is not tested can easily lead to false regression.In this paper, the ADF method is used to test stationarity of these indexed and their 1 and 2 stage differential of the industrial structure and its related influencing factors. The test results are shown in table 1. “***” indicates significant at $1 \%$ level.

Table1 Variables Stationarity Test

\begin{tabular}{ccccccc}
\hline Test sequence & \multirow{2}{*}{$\begin{array}{c}\text { Test form } \\
(\mathrm{C}, \mathrm{T}, \mathrm{K})\end{array}$} & $\begin{array}{c}\text { ADF test } \\
\text { statistic }\end{array}$ & \multicolumn{2}{l}{ The critical value of each significant level } & Test result \\
\cline { 4 - 6 } & & & $1 \%$ & $5 \%$ & $10 \%$ & \\
\hline$L N C F$ & $(\mathrm{C}, \mathrm{T}, 0)$ & -2.519579 & -4.284580 & -3.562882 & -3.215267 & Unstatationary \\
\hline$D L N C F$ & $(\mathrm{C}, \mathrm{N}, 0)$ & $-4.442867^{* * *}$ & -3.670170 & -2.963972 & -2.621007 & Stationary \\
\hline$D D L N C F$ & $(\mathrm{~N}, \mathrm{~N}, 0)$ & $-7.176811^{* * *}$ & -2.647120 & -1.952910 & -1.610011 & Stationary \\
\hline$L N E D U$ & $(\mathrm{~N}, \mathrm{~N}, 0)$ & 4.834914 & -2.641672 & -1.952066 & -1.610400 & Unstatationary \\
\hline$D L N E D U$ & $(\mathrm{C}, \mathrm{N}, 0)$ & $-5.187862^{* * *}$ & -3.670170 & -2.963972 & -2.621007 & Stationary \\
\hline$D D L N E D U$ & $(\mathrm{~N}, \mathrm{~N}, 1)$ & $-6.056672^{* * *}$ & -2.650145 & -1.953381 & -1.609798 & Stationary \\
\hline$L N E U$ & $(\mathrm{C}, \mathrm{T}, 1)$ & -2.780259 & -4.296729 & -3.568379 & -3.218382 & Unstatationary \\
\hline$D L N E U$ & $(\mathrm{~N}, \mathrm{~N}, 0)$ & -1.196135 & -2.644302 & -1.952473 & -1.610211 & Unstatationary \\
\hline$D D L N E U$ & $(\mathrm{~N}, \mathrm{~N}, 0)$ & $-4.642255^{* * *}$ & -2.647120 & -1.952910 & -1.610011 & Stationary \\
\hline$L N I S$ & $(\mathrm{C}, \mathrm{T}, 1)$ & $-4.877486^{* * *}$ & -4.296729 & -3.568379 & -3.218382 & Stationary \\
\hline$D L N I S$ & $(\mathrm{C}, \mathrm{N}, 0)$ & $-3.675251^{* * *}$ & -3.670170 & -2.963972 & -2.621007 & Stationary \\
\hline$D D L N I S$ & $(\mathrm{~N}, \mathrm{~N}, 0)$ & $-7.183141^{* * *}$ & -2.647120 & -1.952910 & -1.610011 & Stationary \\
\hline
\end{tabular}

According to the test results of table 1, the single integration stage of all the variables are different, therefore can not be tested by the cointegration test method. The 2 stage difference of these variables are all stationary, so the GMM method which avoiding the possible endogenous problem among the variables is constructed to analyze the relationship among the 2 stage difference of these variables .

GMM Model. The Generalized Method of Moments (GMM) model of 2 stage difference is shown in the formula (1). The instrument variables are their ownself of these independent variables. The number in the parentheses is the standard error and the T statistics in the brackets.

$$
\begin{aligned}
& D D L N I S=0.046 D D L N C F+0.164 D D L N E D U-0.398 D D L N E U-0.371 A R(1) \\
& \begin{array}{lllr}
(0.020) & (0.018) & (0.145) & (0.105) \\
{[2.373]} & {[8.880]} & {[-2.750]} & {[-3.521]}
\end{array}
\end{aligned}
$$

$$
R^{2}=0.399 \quad A . R^{2}=0.327 \quad D . W .=2.322 \quad \text { Inverted } A R \text { Roots }=-0.37
$$

According to formula (1), international capital flows and education development are helpful to industrial upgrading. Energy consumption is not conducive to industrial upgrading . 


\section{Conclusions}

In this paper, the relationship between international capital flows and industrial upgrading is analyzed by GMM model, and the educational development and energy consumption are introduced as the control variables. Through the analysis, the conclusion of this paper is that international capital flows and education development are helpful to industrial upgrading. Energy consumption is not conducive to industrial upgrading in China.

Therefore, international economic exchanges and cooperation should be strengthened to promote industrial upgrading. In addition, it can promote industrial upgrading through improving education level. The relationship between the energy consumption and the industrial upgrading is in the reverse, which explain that the extensive production mode of high energy consumption is not conducive to industrial upgrading. Therefore, in the policy the extensive mode of economic growth should be changed in energy consumption and intensive production mode should be encouraged to promote industrial upgrading.

\section{References}

[1] Marcel Forster, Markus Jorra, Peter Tillmann, The dynamics of international capital flows: Results from a dynamic hierarchical factor Model. Journal of International Money and Finance. 48 (2014) 101-124.

[2] Jan in't Veld, Robert Kollmann, Beatrice Pataracchia, Marco Ratto, Werner Roeger, International capital flows and the boom-bust cycle in Spain, Journal of International Money and Finance. 48 (2014) 314-335.

[3] Cédric Tille, Eric van Wincoop, International capital flows under dispersed private information, Journal of International Economics. 93 (2014) 31-49.

[4] Keisuke Okada, The interaction effects of financial openness and institutions on international capital flows, Journal of Macroeconomics. 35 (2013) 131-143.

[5] Thorsten Janus, Daniel Riera-Crichton, International gross capital flows: New uses of balance of payments data and application to financial crises, Journal of Policy Modeling. 35 (2013) $16-28$.

[6] Rebecca M. Neumann, The effects of capital controls on international capital flows in the presence of asymmetric Information, Journal of International Money and Finance. 25 (2006) 1010-1027.

[7] Martin D.D. Evans, Viktoria V. Hnatkovska, International capital flows, returns and world financial integration, Journal of International Economics. 92 (2014) 14-33.

[8] Dennis Reinhardt, Luca Antonio Ricci, Thierry Tressel, International capital flows and development: Financial openness matters, Journal of International Economics. 91 (2013) 235-251.

[9] Alberto Martin, Filippo Taddei, International capital flows and credit market imperfections: A tale of two frictions, Journal of International Economics. 89 (2013) 441-452.

[10]Cédric Tille, Eric van Wincoop, International capital flows, Journal of International Economics. 80 (2010) 157-175. 